\title{
Hospital care for adults with cystic fibrosis: an overview and comparison between special cystic fibrosis clinics and general clinics using a patient questionnaire
}

\author{
Sarah Walters, John Britton, Margaret E Hodson
}

\begin{abstract}
Background - Provision of medical care for adult patients with cystic fibrosis is an increasing problem as the number of patients surviving into adulthood increases. Recent reports have suggested that care is best provided in specialist centres because of longer survival. Recent changes in the National Health Service funding and delivery of service may adversely affect the provision of such a specialist service. The aim of this study was to assess the current pattern of medical service received by adults with cystic fibrosis and to compare the type of care between special cystic fibrosis and general clinics.

Methods - Confidential postal questionnaires were sent to all 1052 members of the Association of Cystic Fibrosis Adults (ACFA) comprising $59 \%$ of the UK population of cystic fibrosis patients over 15 years and $80 \%$ over 25 years of age. The response rate was $82 \%$.
\end{abstract}

Department of Public Health and Epidemiology, University of

Birmingham Medical School, Birmingham B15 2TT

$S$ Walters

Department of Respiratory Medicine, City Hospital, Nottingham NG5 1PB J Britton

Department of Respiratory Medicine, National Heart and Lung Institute and Royal Brompton National Heart and Lung Hospital, London SW3 6NP

$M$ E Hodson

Reprint requests to: Dr S Walters

Received 15 February 1993 Returned to authors 8 November 1993 Revised version received 9 December 1993 Accepted for publication 20 December 1993
Results - Two thirds of patients were attending special cystic fibrosis clinics for either adults or adults and children. There were significant differences in the proportion of patients using special cystic fibrosis clinics between regions but not between social class groups. Significant differences between cystic fibrosis and general clinics were noted. Patients attending cystic fibrosis clinics were more likely to have had simple clinical investigations (blood tests, sputum culture, oxygen saturation, chest radiography, weight and lung function measurement) in the previous year. They were also more likely to have received intravenous antibiotics at home, and to have access to paramedical personnel. Patients attending cystic fibrosis clinics were taking higher doses of pancreatic enzyme supplements with respect to quantity and potency of preparation. Such patients also had less severe symptoms irrespective of social class, and were more likely to be satisfied with professional aspects of their care. Regardless of type of clinic, potential deficiencies were identified in overall medical care with omission of clinical investigations in severely affected patients and evidence of undertreated respiratory and digestive symptoms in patients with moderate and severe disease.

Conclusions - This survey provides evidence that adults with cystic fibrosis attending special cystic fibrosis clinics receive more intensive care, have better symptom control, and are more satisfied with the service provided than those attending general clinics.

(Thorax 1994;49:300-306)

Improvements in survival from cystic fibrosis have resulted in a sustained increase in the prevalence of the disease by approximately 100 patients a year. Most of this increase is in adults, ${ }^{1}$ and already over a quarter of patients are over the age of $30 .^{2}$ Recent reports suggest that prevalence and prognosis will continue to improve. ${ }^{23}$ The implication of these observations is that health care services for patients with cystic fibrosis, and particularly adults, will need to expand.

The best way to provide appropriate medical care has, however, been the subject of debate in the UK. In countries where care is organised almost exclusively in specialist centres reported survival rates are superior to those of the UK, ${ }^{4-6}$ suggesting that resources should be invested in specialist clinics. In 1988 only $51 \%$ of all patients with cystic fibrosis in the UK attended what the British Paediatric Association defined as a "specialist centre." Although potentially confounded by effects of social class, survival in these patients was greater than in those attending general clinics. $^{78}$

This evidence prompted both the British Paediatric Association and the Royal College of Physicians to recommend that care should take place in specialist centres, funded by regional health authorities. ${ }^{12}$ These would function as treatment centres and sources of expertise and education where care is shared with a local hospital. In addition, the Royal 
College of Physicians specified the need for a systematic approach to the development of standards of care, setting of quality targets, and allocation of resources. ${ }^{1}$ However, progress towards establishing this model of care for adult patients with cystic fibrosis has been slow. Furthermore, the provision of specialist care is expensive ${ }^{9}$ which, in the light of recent reforms to the National Health Service outlined in Working for patients, ${ }^{1011}$ could act as a disincentive to the purchasing of specialist care for adult patients with cystic fibrosis and further compromise rational service planning and development.

This survey was designed to document the demographic and social characteristics of adults with cystic fibrosis in the UK and, in particular, to identify the medical services they received. Additional aims were to compare the delivery of treatment and patient satisfaction between special cystic fibrosis clinics and noncystic fibrosis clinics, and to serve as a baseline against which to monitor future changes in hospital care resulting from health service reforms. The social and demographic characteristics of the patients have been published separately, ${ }^{12}$ and this paper presents details of the provision of medical care.

\section{Methods \\ PATIENTS \\ Membership of the Association of Cystic Fibrosis Adults (ACFA) extends to approxim- ately $68 \%$ of the UK population with cystic fibrosis aged over 16 years, and to over $80 \%$ of those over 25 years of age. A confidential self administered postal questionnaire was sent to 1052 eligible ACFA members known to be over 16 years of age on 1 July 1990 , and followed by two reminders. The sample in- cluded patients attending large special cystic fibrosis clinics and general clinics at local hos- pitals.}

DEFINITION OF CYSTIC FIBROSIS AND GENERAL CLINICS

Those attending clinics exclusively for patients with cystic fibrosis were defined as attending cystic fibrosis clinics, and those who did not were defined as attending general clinics.

\section{QUESTIONNAIRE}

The multiple choice questionnaire included questions covering social and demographic information, primary and secondary hospital care, and medication. Severity of disease was estimated using a standard symptom questionnaire with a summary score calculated as the average of five symptoms (breathlessness, cough, sputum, abdominal discomfort, fatigue) each rated on a scale of one to five. This was internally validated against other measures of disease severity such as percentage ideal weight for height, annual sick leave from work, and annual time spent in hospital. A score of $\leqslant 2 \cdot 0$ represented mild symptoms, $2 \cdot 1-3 \cdot 4$ represented moderate symptoms, and $\geqslant 3.5$ represented severe symptoms.

Patients were asked to identify the hospital they attended and the type of doctor (paediatrician, chest physician, etc) as well as whether the clinic they attended was only for patients with cystic fibrosis (adults or children) or was a general clinic treating a number of medical or paediatric conditions. They were also asked to recall their contact with paramedical personnel, their current medication, and investigations which had been performed in the previous year at the hospital, reported in the questionnaire. Although there was no direct access to patient records to validate the responses, adults with cystic fibrosis attending hospitals with large cystic fibrosis clinics correctly identified them in $91 \%$ of cases.

Patient satisfaction was assessed using several professional and non-professional aspects of care together with an overall rating.

\section{DATA ANALYSIS}

Data were analysed by the Epi-Info statistical package and the BMJ Confidence Intervals Analysis package using, where appropriate, $\chi^{2}$, Mantel-Haenszel, analysis of variance, and confidence intervals for single proportions and the difference between proportions. Not all respondents answered all questions, and analysis for each question is confined only to those who made valid responses.

\section{Results}

The response rate was $82 \cdot 3 \%(n=866)$, representing $56 \%$ of the total number of adults with cystic fibrosis in the UK.

\section{TYPE OF HOSPITAL CARE}

A total of 669 patients $(82 \%)$ identified a hospital they were attending for their care. Of these $411(61 \%)$ were attending at least one hospital which provided a large clinic for patients with cystic fibrosis in a major city. More than one hospital was named by $21 \%$ of patients, indicating the development of shared care arrangements, usually between local hospitals and special cystic fibrosis clinics.

Using the definition given above, 494 of 746 patients $(66 \%)$ were attending a cystic fibrosis clinic and $252(34 \%)$ were attending a general clinic (table 1). There were social class differences in both type of clinic attended and type of doctor seen, largely because of the higher proportion of patients from manual social classes who were still attending cystic fibrosis specialist paediatricians. In this study cystic fibrosis clinics included those for adults, children, or both, which removed the difference due to social class leaving only the balance between adult and paediatric care (table 1).

There was a difference in disease severity between patients attending cystic fibrosis clinics and general clinics (mean symptom score 2.33 for cystic fibrosis and 2.51 for general clinics, $\mathrm{p}<0.005$ Mann-Whitney U 
Table 1 Type of hospital doctor seen and type of clinic attended by adult cystic fibrosis questionnaire respondents, by social class group

\begin{tabular}{|c|c|c|c|c|c|}
\hline & $\begin{array}{l}\text { Overall } \\
\text { number } \\
0 \%\end{array}$ & $\begin{array}{l}\text { Manual } \\
\text { social class } \\
\text { number } \\
\text { " }\end{array}$ & $\begin{array}{l}\text { Non-manual } \\
\text { social class } \\
\text { number } \\
{ }_{0}\end{array}$ & $\begin{array}{l}95^{\circ} \text { "CI for difference } \\
\text { between mamual and } \\
\text { non-manual }\end{array}$ & $\begin{array}{l}\text { Mean } \\
\text { sl'mptom } \\
\text { score of } \\
\text { group }\end{array}$ \\
\hline \multicolumn{6}{|l|}{ Type of doctor seen } \\
\hline $\begin{array}{l}\text { Chest physician } \\
\text { specialising in cystic } \\
\text { fibrosis }\end{array}$ & $\begin{array}{l}482 \\
(65 \cdot 2 \%)\end{array}$ & $\frac{111}{(57.5 \%}$ & $\begin{array}{l}363 \\
68 \cdot 0^{\prime \prime}(0)\end{array}$ & $2 \cdot 5^{\circ}{ }_{10}$ to $-18 \cdot 5^{0}{ }_{10}^{*}$ & $2 \cdot 40$ \\
\hline $\begin{array}{l}\text { Non-specialist chest } \\
\text { physician }\end{array}$ & $\begin{array}{l}124 \\
\left.16 \cdot 8^{\circ} \circ\right)\end{array}$ & $\begin{array}{l}32 \\
\left.16 \cdot 6^{\prime \prime}\right)\end{array}$ & $\begin{array}{l}89 \\
16.7^{\prime \prime \prime}\end{array}$ & $6 \cdot 0^{\circ}{ }_{0}$ to $6.0^{\circ} \circ$ & 2.51 \\
\hline $\begin{array}{l}\text { Non-specialist general } \\
\text { physician }\end{array}$ & & & & $-0 \cdot 4^{\prime \prime}$, to $7 \cdot 2^{\prime \prime \prime}$ & $2 \cdot 47$ \\
\hline $\begin{array}{l}\text { Paediatrician } \\
\text { specialising in cystic } \\
\text { fibrosis }\end{array}$ & $\begin{array}{l}70 \\
(9 \cdot 5 \%)\end{array}$ & $\begin{array}{l}26 \\
(13 \cdot 5 \%)\end{array}$ & $\begin{array}{l}43 \\
\left(8 \cdot 1^{\circ}{ }^{\prime \prime \prime}\right)\end{array}$ & $0 \cdot 01^{\prime \prime}{ }_{0}$ to $10 \cdot 8^{\circ}{ }_{0}^{*}$ & $2 \cdot 22$ \\
\hline $\begin{array}{l}\text { Non-specialist } \\
\text { paediatrician }\end{array}$ & $\begin{array}{l}18 \\
\left.2 \cdot 4^{\prime \prime}\right)\end{array}$ & $\stackrel{6}{\left(3 \cdot 1^{\prime \prime}\right)}$ & $\begin{array}{l}12 \\
2 \cdot 2^{\prime \prime} 0\end{array}$ & $1 \cdot 9^{\circ}$ " to $3 \cdot 4^{\prime \prime}$ " & $2 \cdot 26$ \\
\hline Other & $\begin{array}{l}14 \\
(1.9 \%)\end{array}$ & $\begin{array}{c}5 \\
\left(2 \cdot 6^{\circ}\right)\end{array}$ & $\stackrel{9}{\left(1 \cdot 7^{\prime \prime}\right)}$ & $1 \cdot 6^{\prime \prime}$, to $3 \cdot 4^{\circ} \%$ & $2 \cdot 17$ \\
\hline Total & 739 & 193 & 534 & & \\
\hline \multicolumn{6}{|l|}{ Type of clinic attended } \\
\hline $\begin{array}{l}\text { For cystic fibrosis } \\
\text { adults only }\end{array}$ & $\begin{array}{l}376 \\
\left(50 \cdot 4^{0} *\right)\end{array}$ & $\begin{array}{l}85 \\
43 \cdot 8^{\circ}\end{array}$ & $\frac{282}{52 \cdot 4^{\prime \prime}}$ & $-16 \cdot 8^{\prime \prime}$ " to $-44^{\prime \prime}{ }^{*}$ & $2 \cdot 37$ \\
\hline $\begin{array}{l}\text { For cystic fibrosis } \\
\text { adults and children }\end{array}$ & $\begin{array}{l}118 \\
(15 \cdot 8 \%)\end{array}$ & $\begin{array}{l}35 \\
(18.0 \%\end{array}$ & $\begin{array}{l}81 \\
15 \cdot 1 "\end{array}$ & $-3 \cdot 2^{\prime \prime}$, to $9 \cdot 2^{\circ}{ }^{\circ}$ & $2 \cdot 23$ \\
\hline $\begin{array}{l}\text { For patients with all } \\
\text { sorts of medical } \\
\text { conditions }\end{array}$ & $\begin{array}{l}222 \\
29 \cdot 8 \%\end{array}$ & $\begin{array}{l}65 \\
\left.33.5^{\circ} \circ\right)\end{array}$ & $\begin{array}{l}155 \\
\left.28 \cdot 8^{\prime \prime} \circ\right)\end{array}$ & $-2 \cdot 9^{\circ} "$ to $12 \cdot 4^{\prime \prime \prime}$ & $2 \cdot 52$ \\
\hline Don't know & $\begin{array}{l}18 \\
2 \cdot 4^{\circ} 0\end{array}$ & $\begin{array}{l}8 \\
41^{\circ} 0\end{array}$ & $\begin{array}{c}9 \\
\left(1 \cdot 7^{\prime \prime}\right)\end{array}$ & $1-5^{\prime \prime}$ " to $5 \cdot 4^{\prime \prime}$ 。 & $2 \cdot 40$ \\
\hline $\begin{array}{l}\text { Other, e.g. attend } \\
\text { ward or do not attend } \\
\text { hospital }\end{array}$ & $\begin{array}{l}12 \\
(1.6 \%)\end{array}$ & $(0.5 \%)$ & $(2.0 \%)$ & $-3 \cdot 1^{\circ}{ }^{\circ}$ to $0.03^{\circ} \circ$ & $2 \cdot 40$ \\
\hline Total & 746 & 194 & 538 & & \\
\hline $\begin{array}{l}\text { All special cystic fibrosis } \\
\text { clinics }\end{array}$ & $\begin{array}{l}494 \\
\left(66 \cdot 2^{\circ}\right)\end{array}$ & $\begin{array}{l}120 \\
61.9^{\circ} \%\end{array}$ & $\begin{array}{l}363 \\
\left(67.5^{\prime \prime}\right)\end{array}$ & $-13 \cdot 5^{\prime \prime}$ o to $2 \cdot 3^{\circ}$ & $2 \cdot 33$ \\
\hline All general clinics & $\begin{array}{l}252 \\
(33.8 \%)\end{array}$ & $\begin{array}{l}74 \\
(38 \cdot 1 \%)\end{array}$ & $\begin{array}{l}175 \\
(32.5 \%)\end{array}$ & $-2 \cdot 3^{\prime \prime}$. to $13 \cdot 5^{\circ} \%$ & $2 \cdot 49$ \\
\hline
\end{tabular}

${ }^{*} \mathrm{p}<0.05$ for difference between manual and non-manual groups. test). This was mainly because of differences within the non-manual social class group (mean score $2 \cdot 27$ cystic fibrosis clinics, 2.45 general clinics, $\mathrm{p}<0.02$ Mann-Whitney $\mathrm{U}$ test), and not to differences in the social class composition of the two groups.

The proportion of patients attending cystic fibrosis clinics also differed between regional health authorities (fig 1). There were differences in distance travelled to hospital; 117 of $493(24 \%)$ patients attending cystic fibrosis clinics had to travel over 50 miles compared with only 19 of $248(8 \%)$ of those attending general clinics $\left(95^{\circ}, \mathrm{CI}\right.$ for difference $11 \cdot 1 \%$ to $21 \cdot 1 \%$ ).

\section{OUTPATIENT CARE}

Those patients attending clinic more frequently had more severe disease, regardless of clinic type. Patients attending general clinics were more likely to attend very frequently (once a month) (45 of $249(18 \%)$ attending general clinics compared with 52 of 493 $(11.2 \%)$ attending cystic fibrosis clinics, 95\% CI for difference $2.03 \%$ to $13.0 \%$ ), or infrequently (every 5-6 months) (37 of 249 (14\%) attending general clinics compared with 39 of $493(8 \%)$ attending clinics, 95\% CI for difference $1.9 \%$ to $12.0 \%$ ). A higher proportion of those attending cystic fibrosis clinics had direct access to the consultant or cystic fibrosis team without first having to consult their general practitioner (474 of $485(98 \%)$ compared with 193 of $226(85 \%)$ in general clinics, $95 \%$ CI $7 \cdot 53 \%$ to $17 \cdot 1 \%$ ).

A higher proportion of patients attending cystic fibrosis clinics had sputum culture, blood gases, oxygen saturation, weight and chest radiographs performed in the previous year than those attending general clinics (table 2 ). Such differences were irrespective of disease severity.

PARAMEDICAL PERSONNEL

Those patients attending cystic fibrosis clinics were more likely to have seen paramedical personnel (table 3 ) irrespective of disease severity $\left(\chi_{\mathrm{MH}}^{2}\right.$ for dietitian 9.00, $\mathrm{p}<0.005$; physiotherapist $21.20, \quad \mathrm{p}<0.001$; medical social worker 8.74, $\mathrm{p}<0.005)$. The mean symptom score was significantly greater in those who had seen both dietitians and physiotherapists regardless of clinic type. Patients who had recently seen a dietitian were more often receiving food supplements (301 of 462

Figure 1 Proportion of cystic fibrosis adult questionnaire respondents attending special cystic fibrosis clinics by RHA or country of residence.

Table 2 Clinical investigations performed on adult cystic fibrosis questionnaire respondents in the previous year: a comparison of those attending general and special cystic fibrosis clinics. Blood gases include measurement of transcutaneous oxygen saturation

\begin{tabular}{|c|c|c|c|c|c|}
\hline $\begin{array}{l}\text { Type of } \\
\text { investigation }\end{array}$ & $\begin{array}{l}\text { Overall } \\
\text { number } \\
(\%)\end{array}$ & $\begin{array}{l}\text { General clinics } \\
\text { number } \\
\%\end{array}$ & $\begin{array}{l}\text { Cystic fibrosis } \\
\text { clinics number } \\
\%\end{array}$ & $\begin{array}{l}95 \% \text { CI for difference } \\
\text { between cystic fibrosis } \\
\text { and general clinics }\end{array}$ & $\begin{array}{l}\text { Wh stratified by symptom } \\
\text { severity for difference between } \\
\text { cystic fibrosis and general clinics }\end{array}$ \\
\hline Blood tests & $645(85.8 \%)$ & $208(82.7 \%)$ & $437(87 \cdot 4 \%)$ & $-10.4 \%$ to $0.65^{\circ} \%$ & $2.32(p>0.1$ \\
\hline Blood gases & $366(48 \cdot 7 \%)$ & $89\left(35.3^{\circ} \%\right)$ & $279(55.7 \%$ & $-27 \cdot 8^{\circ}{ }_{0}$ to $13 \cdot 1^{\circ} 0^{*}$ & $23.5(\mathrm{p}<0.001)^{*}$ \\
\hline Lung function & $579(77.0 \%)$ & $186(73.9 \%)$ & $393(78 \cdot 6 \%)$ & $-11.3^{\circ}$ o to $1.72^{\circ} \circ$ & $1.57(\mathrm{p}>0.1)$ \\
\hline Sputum culture & $653(86 \cdot 9 \%)$ & $207(81 \cdot 6 \%)$ & $449\left(89 \cdot 7^{\circ}\right)$ & $-13 \cdot 1^{\circ}$ o to $2 \cdot 4^{\circ} 0^{*}$ & $8.88(p<0.01)^{*}$ \\
\hline Weight & $702(93.4 \%)$ & $224(89.0 \%)$ & $479(95 \cdot 7 \%)$ & $-11 \cdot 2^{\prime \prime}$ oto $-2 \cdot 7^{\circ} \%^{*}$ & $5.61(\mathrm{p}<0.02)^{*}$ \\
\hline Chest radiograph & $683(90 \cdot 8 \%)$ & $219(86.9 \%)$ & $464(92.9 \%)$ & $-10 \cdot 6 \%$ to $-1.2 \%{ }^{*}$ & $4.96(\mathrm{p}<0.05)^{*}$ \\
\hline & 752 & 252 & 500 & & \\
\hline
\end{tabular}


Table 3 Paramedical personnel seen by adult cystic fibrosis questionnaire respondents in the previous year: a comparison between those attending cystic fibrosis clinics and general clinics

\begin{tabular}{|c|c|c|c|c|}
\hline Person seen & $\begin{array}{l}\text { Overall } \\
\text { number } \\
(\%)\end{array}$ & $\begin{array}{l}\text { General clinics } \\
\text { number } \\
(\%)\end{array}$ & $\begin{array}{l}\text { Cystic fibrosis } \\
\text { clinics number } \\
(\%)\end{array}$ & $\begin{array}{l}95 \% \text { CI for difference } \\
\text { between cystic fibrosis } \\
\text { and general clinics }\end{array}$ \\
\hline \multirow{2}{*}{$\begin{array}{l}\text { Dietitian } \\
\text { Physiotherapist } \\
\text { Medical social worker } \\
\text { Cystic fibrosis clinical } \\
\text { nurse specialist } \\
\text { n }\end{array}$} & $\begin{array}{l}462(61 \cdot 7 \%) \\
543(72 \cdot 5 \%) \\
180(24 \cdot 0 \%) \\
144(19 \cdot 2 \%)\end{array}$ & $\begin{array}{c}137(54 \cdot 4 \%) \\
157(62 \cdot 3 \%) \\
46(18 \cdot 3 \%) \\
20(7 \cdot 9 \%)\end{array}$ & $\begin{array}{l}322(65 \cdot 3 \%) \\
383(77 \cdot 7 \%) \\
133(27 \cdot 0 \%) \\
123(24 \cdot 9 \%)\end{array}$ & \multirow[t]{2}{*}{$\begin{array}{l}-18.4 \% \text { to }-3.5 \% * \\
-22.4 \% \text { to }-8.4 \% \%^{*} \\
-14.9 \% \text { to }-2.55 \% * \\
-22.1 \% \text { to }-11.9 \%\end{array}$} \\
\hline & $749 \dagger$ & 252 & 493 & \\
\hline
\end{tabular}

* $\mathrm{p}<0.05$.

+ Some patients not attending any clinics included in overall total.

$(65 \%) v 82$ of $287(29 \%), 95 \%$ CI difference $29.8 \%$ to $43.3 \%$ ) and to have received advice to increase fat intake ( 278 of $455(61 \%) v 88$ of $276(32 \%), 95 \%$ CI difference $22 \cdot 1 \%$ to $36.3 \%$ ) irrespective of disease severity (Mantel-Haenszel $\chi^{2}$ for both $\left.\mathrm{p}<0.001\right)$. Patients who had recently seen a medical social worker were more likely to have applied for mobility allowance (113 of $162(67 \%) v 192$ of 492 (39\%), $95 \%$ CI difference $19.9 \%$ to $36 \cdot 5 \%$ ) and attendance allowance (113 of $162(70 \%) v$ 203 of $490(42 \%), 95 \%$ CI difference $20 \%$ to $36.8 \%$ ) irrespective of disease severity, with no change in the refusal rate.

\section{INPATIENT CARE}

Admission to hospital had not been required for 379 of $747(51 \%)$ patients in the last year. The mean (SD) number of hospital admissions was $1.65(2.77)$. There were no differences in the frequency of hospital admissions between clinic types or social class groups. Inpatient facilities differed with more cystic fibrosis clinics providing single rooms for patients with cystic fibrosis (302 of $448(67 \%) v 46$ of $222(21 \%), 95 \%$ CI difference $39.8 \%$ to $53.6 \%$ ) and having activity rooms (198 of 427 $(46 \%) v 34$ of $214(16 \%), 95 \%$ CI $23.7 \%$ to $37 \cdot 3 \%$ ). Patients admitted from cystic fibrosis clinics were more likely to be allowed to keep and administer their own medication (359 of $411(87 \%) v 141$ of $199(70 \%), 95 \%$ CI $9.4 \%$ to $23 \cdot 6 \%$ ).

HOME INTRAVENOUS ANTIBIOTIC THERAPY

Those attending cystic fibrosis clinics received more self administered intravenous therapy at home (260 of $491(53 \%) v 78$ of $252(31 \%)$, $95 \%$ CI difference $14.8 \%$ to $29 \cdot 2 \%$ ). This difference was independent of differences in disease severity (Mantel-Haenszel $\chi^{2} 32.39$, $\mathrm{p}<0.001$ ). Those receiving home intravenous therapy had more severe disease regardless of type of clinic attended (symptom score $2.52 v$ 2.30 in those not receiving home intravenous therapy, $95 \%$ CI difference 0.116 to 0.322 ), and spent more time in hospital in the preceding year, with 95 of $339(28 \%)$ patients who received home intravenous therapy spending four weeks or more in hospital compared with 54 of $408(13 \%)$ patients not receiving home intravenous therapy $(95 \%$ CI difference $8.99 \%$ to $20.6 \%$ ). Home intravenous antibiotic therapy does not appear to prevent hospital admission but is used as an adjunct to hospital treatment in a group with more severe disease.

\section{MEDICATION AND DIET}

The dose of pancreatic enzymes taken with meals and snacks was greater in cystic fibrosis than in general clinics, and stratified analysis showed this to be independent of disease severity (Mantel-Haenszel $\chi^{2} p<0.05$ ). The mean dose with meals was 6.7 capsules in patients attending cystic fibrosis clinics and 5.50 in those attending general clinics $(95 \%$ CI difference 0.34 to 1.76 ). Comparable mean doses for snacks were 2.97 and 2.36 capsules respectively (95\% CI 0.12 to 0.91$)$. The dose of pancreatic enzymes taken was associated with perceived severity of digestive disease $\left(p<0.001, \chi^{2}\right.$ test $)$ and negatively correlated with percentage predicted weight for height $(r=-0 \cdot 14,95 \%$ CI -0.21 to -0.07$)$.

Of those attending cystic fibrosis clinics 454 of $494(88 \%)$ were taking microsphere pancreatic preparations as opposed to older less effective preparations, compared with 225 of $252(81 \%)$ at general clinics $(95 \%$ CI difference $0.7 \%$ to $9.7 \%$ ), and this difference was independent of disease severity (MantelHaenszel $\left.\chi^{2} 4.78, p<0.05\right)$. Patients attending cystic fibrosis clinics and those taking microsphere pancreatic enzyme preparations had slightly greater body weight, but comparisons are likely to be confounded by patients with more severe digestive problems preferentially receiving microsphere pancreatic enzyme preparations. Newer high lipase preparations were not available at the time of this survey.

There was no difference between cystic fibrosis clinics and general clinics in the proportion restricting dietary fat intake (126 of $490,26 \%$ ), or in the proportion who had been recently advised to increase their fat intake (363 of $728,50 \%$ ). However, patients attending general clinics were more likely to restrict their fat intake because of unacceptable symptoms rather than other reasons (44 of 252 (18\%) compared with 54 of $494(11 \%)$ at cystic fibrosis clinics, $95 \%$ CI $1 \cdot 1 \%$ to $12.0 \%$ ). Of the adults with cystic fibrosis $13 \%$ inappropriately restricted their fat intake as a result of general health promotion messages aimed at the non-cystic fibrosis population. A proprietary food supplement was taken by 368 of 746 $(49 \%)$ patients, but there was no difference between cystic fibrosis and general clinics.

Nebulised antibiotics were taken by 256 of $746(34 \%)$ patients with or without bronchodilator, and the proportion was slightly greater in those attending cystic fibrosis clinics. The use of nebulised medication was related to severity of symptoms of cough, breathlessness, and sputum production $\left(\chi^{2} \mathrm{p}<0.001\right)$, and also to the patient's own perception of chest disease as severe.

\section{SATISFACTION WITH HOSPITAL CARE}

Overall, 156 of $686(23 \%)$ patients did not rate their care as good (table 4). In general the professional aspects of care received a more 
Table 4 Satisfaction of adult cystic fibrosis questionnaire respondents with various aspects of hospital care: a comparison between general and special cystic fibrosis clinics

\begin{tabular}{|c|c|c|c|c|c|c|c|c|c|}
\hline \multirow[t]{2}{*}{ Aspect of care } & \multicolumn{5}{|c|}{ Grade given number $(\%)$} & \multicolumn{2}{|c|}{ Mean grade } & \multirow{2}{*}{$\begin{array}{l}95 \% \text { CI difference } \\
\text { between cystic } \\
\text { fibrosis and } \\
\text { general clinics }\end{array}$} & \multirow{2}{*}{$n$} \\
\hline & 1 (very poor) & 2 (poor) & 3 (fair) & 4 (good) & 5 (very good) & $\begin{array}{l}\text { General } \\
\text { clinics }\end{array}$ & $\begin{array}{l}\text { Cystic } \\
\text { fibrosis } \\
\text { clinics }\end{array}$ & & \\
\hline $\begin{array}{l}\text { Hospital accommodation } \\
\text { Hospital food } \\
\text { Consultant's knowledge of cystic } \\
\text { fibrosis }\end{array}$ & $\begin{array}{c}12(1.9 \%) \\
101(16 \cdot 1 \%) \\
5(0 \cdot 7 \%)\end{array}$ & $\begin{array}{c}39(6 \cdot 2 \%) \\
146(23 \cdot 3 \%) \\
9(1 \cdot 3 \%)\end{array}$ & $\begin{array}{c}205(32.5 \%) \\
216(34.5 \%) \\
49(7 \cdot 1 \%)\end{array}$ & $\begin{array}{l}238(37 \cdot 7 \%) \\
123(19 \cdot 6 \%) \\
125(18 \cdot 2 \%)\end{array}$ & $\begin{array}{c}135(21 \cdot 4 \%) \\
36(5 \cdot 8 \%) \\
498(72 \cdot 6 \%)\end{array}$ & $\begin{array}{l}3 \cdot 64 \\
2 \cdot 73 \\
4 \cdot 33\end{array}$ & $\begin{array}{l}3 \cdot 74 \\
2 \cdot 76 \\
4 \cdot 74\end{array}$ & $\begin{array}{l}-0.26 \text { to } 0.06 \\
-0.22 \text { to } 0.16 \\
-0.53 \text { to }-0.29 *\end{array}$ & $\begin{array}{l}636 \\
631 \\
690\end{array}$ \\
\hline $\begin{array}{l}\text { Consultant's understanding of your } \\
\text { problems }\end{array}$ & $12(1 \cdot 8 \%)$ & $32(4 \cdot 7 \%)$ & $105(15 \cdot 4 \%)$ & $197(28 \cdot 8 \%)$ & $337(49 \cdot 3 \%)$ & 3.93 & $4 \cdot 31$ & -0.54 to -0.23 & 687 \\
\hline $\begin{array}{l}\text { Junior doctors' understanding of } \\
\text { cystic fibrosis }\end{array}$ & $20(3 \cdot 1 \%)$ & $71(11 \cdot 1 \%)$ & $220(34 \cdot 3 \%)$ & $226(35 \cdot 3 \%)$ & $101(15 \cdot 8 \%)$ & $3 \cdot 13$ & $3 \cdot 65$ & -0.68 to $-0.36^{*}$ & 645 \\
\hline $\begin{array}{l}\text { Nurses' understanding of cystic } \\
\text { fibrosis }\end{array}$ & $17(2 \cdot 6 \%)$ & $50(7 \cdot 6 \%)$ & $180(27 \cdot 4 \%)$ & $245(73 \cdot 1 \%)$ & $133(29 \cdot 9 \%)$ & $3 \cdot 27$ & 3.93 & -0.81 to $-0.51^{*}$ & 662 \\
\hline Physiotherapy advice you receive & $8(1.3 \%)$ & $20(3 \cdot 1 \%)$ & $79(12 \cdot 4 \%)$ & $223(35 \cdot 0 \%)$ & $297(46 \cdot 6 \%)$ & 3.97 & $4 \cdot 27$ & -0.47 to $-0.13^{*}$ & 642 \\
\hline Dietary advice you receive & $29(4.9 \%)$ & $39(6 \cdot 6 \%)$ & $125(21 \cdot 2 \%)$ & $195(33 \cdot 1 \%)$ & $182(30 \cdot 8 \%)$ & $3 \cdot 23$ & $3 \cdot 86$ & -0.83 to $-0.36^{*}$ & 694 \\
\hline Social work advice you receive & $72(19 \cdot 7 \%)$ & $31(8.5 \%)$ & $83(22 \cdot 7 \%)$ & $84(23.0 \%)$ & $52(14 \cdot 2 \%)$ & $2 \cdot 24$ & $2 \cdot 89$ & $-1 \cdot 00$ to $-0 \cdot 30^{*}$ & 369 \\
\hline Overall rating of hospital care & $12(1 \cdot 8 \%)$ & $24(3.5 \%)$ & $120(17 \cdot 6 \%)$ & $278(40 \cdot 8 \%)$ & $247(36 \cdot 3 \%)$ & $3 \cdot 76$ & $4 \cdot 20$ & -0.58 to $-0.29^{*}$ & 686 \\
\hline
\end{tabular}

${ }^{*} \mathrm{p}<0.05$.

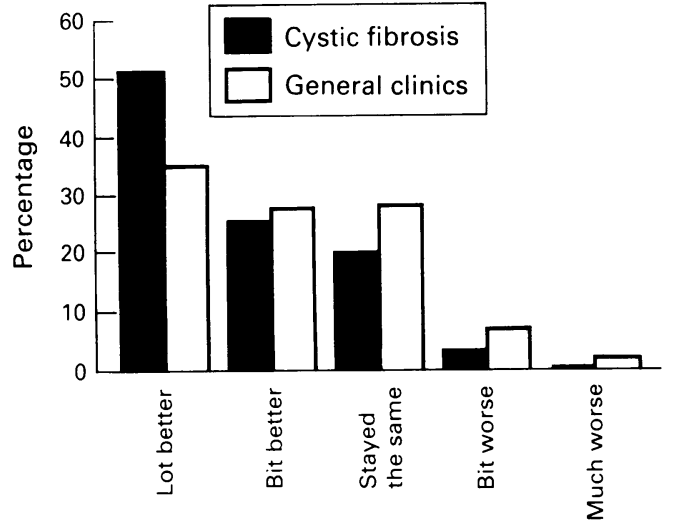

Change in care over five years

Figure 2 Cystic fibrosis adult questionnaire respondents' perceptions of the change in medical care they have received over the past five years - general and cystic fibrosis clinics compared. Overall $p<0.001, \chi^{2}$.

favourable rating than the hotel aspects, in particular hospital food. There were differences between cystic fibrosis and general clinics for professional but not hotel aspects of care. Patients attending cystic fibrosis clinics were more likely to report that their care had improved over the previous five years (fig 2).

\section{Discussion}

This survey was planned to answer two questions: (1) to what extent do adult patients with cystic fibrosis receive the type of care recommended by the Royal College of Physicians, ${ }^{2}$ and (2) in what ways do the processes of medical care and satisfaction with medical care differ between patients attending special cystic fibrosis clinics and general clinics?

\section{SAMPLE AND BIAS}

Although a high proportion $(69 \%)$ of adults with cystic fibrosis in the UK are known to ACFA (UK), this sample is still likely to be biased towards those attending large cystic fibrosis clinics where membership tends to be encouraged. Responders were more likely to be female, and although there might be an overall bias in responders towards those of higher social and educational status, in the responders there was no social class bias in those attending cystic fibrosis clinics. It remains likely that this survey overestimates the proportion of patients attending special clinics, and underestimates the differences in care between clinic types.

The internal validity of responses was high. Although the type of care received relied on recall by patients in this study, adults with cystic fibrosis are generally very aware of their disease, the types of treatment and investigations required, and are responsible for a complex daily regimen of care which requires them to be fully aware of their medication. Most patients have many years' experience of hospital treatment and care. It is possible that socially disadvantaged patients attending general clinics are less accurate in response or recall, but this could not be evaluated.

\section{ACCESS TO SPECIALIST CARE}

The British Paediatric Association and the Royal College of Physicians have recommended specialist centres as the basis of medical care for patients with cystic fibrosis. ${ }^{12}$ This survey identified a substantial minority of patients who were not receiving specialist care through cystic fibrosis clinics and significant inequalities in access to such services throughout the UK. One quarter of patients in this sample did not attend a cystic fibrosis specialist doctor or clinic. Patients from manual social classes and in certain areas of the country have lower access, particularly to services for adult patients. Some patients attending special cystic fibrosis clinics still attended paediatricians, which may not be appropriate either for the adult patients or other children on the paediatric wards.

\section{PROCESS OF MEDICAL CARE}

This study highlights differences in the delivery of medical care between cystic fibrosis and general clinics. The care given in cystic fibrosis clinics appears to be more intensive, with more direct access to medical advice, more access to home intravenous therapy, more access to dietitians, physiotherapists and other paramedical personnel, more access to basic investigations to monitor progress, and a higher level of therapy, particularly with pan- 
creatic enzyme supplements. Such differences were independent of overall disease severity. Cystic fibrosis clinics also had more amenities such as activity rooms, and were more likely to allow adult patients to keep and administer their own medication. Patients attending general clinics were more likely to see the consultant, which probably reflects the increased availability of dedicated junior medical staff and research fellows in cystic fibrosis clinics, and did not have any impact on patient satisfaction.

Whilst there is evidence that care in both clinic types is being directed towards those in most need, this study has shown that there are patients who could benefit from more treatment or care, but are not currently receiving it. For example, in the group of patients who were under $85 \%$ predicted weight for height, 38 were taking fewer than four enzyme capsules a meal and 41 had not seen a dietitian in the last year.

Many of these process measures relate to aspects of care considered desirable either by learned bodies, ${ }^{2}$ individual physicians, ${ }^{13}$ or the adult patients themselves. ${ }^{1415}$ While not all clinical investigations or treatments are appropriate for all patients, it seems reasonable to expect that basic investigations such as weight, lung function testing, chest radiography, blood tests, oxygen saturation and sputum culture should be performed in the course of a year. Many patients, even those with severe symptoms, could not recall these being performed in the last year.

\section{OUTCOME OF MEDICAL CARE}

It is not possible to determine outcome from a single survey such as this, although a follow up study of this cohort is planned in 1994-5, four years after the survey reported here, to assess this more fully. Patients attending specialist clinics had less severe symptoms irrespective of social class, which may reflect more intensive monitoring, treatment and access to specialist personnel, although this difference may be due to psychological as well as physical benefits. There is also evidence that those attending cystic fibrosis clinics have better control of digestive symptoms, avoiding the need for dietary fat restriction because of unacceptable symptoms. Although the lower symptom score in patients attending cystic fibrosis clinics may reflect self selection of patients patients living a long way from such a clinic may only be able to undertake the journey if they are fit enough - one might also expect the more severely affected individuals to attend cystic fibrosis clinics as tertiary referrals.

\section{PATIENT SATISFACTION}

Patients attending cystic fibrosis clinics were more satisfied with the professional aspects of their care and perceived their care as having improved over the previous five years. Adult patients with cystic fibrosis frequently have good understanding of their disease and are critical of poor standards of knowledge or care.
Overall, over one third did not rate the hospital care they received as good, with particular dissatisfaction expressed with hospital food and social work advice.

\section{HOSPITAL CARE FOR ADULTS WITH CYSTIC} FIBROSIS

Expert consensus supports care for adults with cystic fibrosis at specialist centres with defined quality standards, ${ }^{12}$ a view shared by most patients themselves, ${ }^{15}$ and supported by this study. Whilst such care is available to most patients, there are still substantial numbers for whom it is not. This study has identified inequalities in access to cystic fibrosis clinics, differences in intensity of care between cystic fibrosis and general clinics, and evidence that some patients are receiving suboptimal care.

Although it may be desirable, care which takes place wholly within specialist cystic fibrosis clinics has potential disadvantages. Some adults with cystic fibrosis prefer locally based treatment. Patients have to travel further to attend special cystic fibrosis clinics. Concentration of care in a single centre may lead to reduction in general awareness in other hospitals of cystic fibrosis in adults. If care is centralised there need to be mechanisms for disseminating expertise to local clinicians so that the centre acts as a resource for the region it serves. This might be achieved by the use of formal shared care arrangements with local hospitals, and educational programmes.

Regional health authorities have an average of 100-150 resident adult patients with cystic fibrosis, whereas district health authorities have only 10-20. With such small numbers, specific purchasing of care by district health authorities may be difficult. Leaving their care to the extracontractual referral mechanism may lead to further difficulties in access to specialist clinics and may compromise the planning and development of specialist services. This study has shown some evidence that care in special cystic fibrosis clinics may be of benefit to patients, with improved symptom control and more intensive treatment and monitoring. Whether the latter confers significant clinical benefit and improves social outcome requires prospective evaluation in the planned follow up survey. Patients are certainly more satisfied with this type of care. If purchasing decisions are to be made in favour of cystic fibrosis clinic care, patient numbers suggest that this might be most appropriately done above single district level.

This study provides evidence that a substantial minority of adults with cystic fibrosis still do not receive care in special cystic fibrosis clinics as recommended by the Royal College of Physicians. ${ }^{2}$ There is evidence that the type of care differs between special cystic fibrosis clinics and general clinics, with greater intensity of treatment and investigation, greater access to paramedical team members, and better symptom control in those attending special cystic fibrosis clinics. Patient satisfaction is higher in those attending cystic fibrosis clinics. This provides supporting evidence for 
the concept of specialist centres of treatment, and highlights areas for improvement, although the question of whether specialist care confers benefit in terms of clinical status, social outcome, and survival remains to be answered. It is hoped that those responsible for purchasing health care, and those who provide care for adults with cystic fibrosis, will recognise the challenges it poses to provide high quality care for all adult patients with cystic fibrosis.

This study was funded by the Cystic Fibrosis Research Trust. The authors would like to thank Sarah Sweetland at the Cystic Fibrosis Research Trust for help in administering the questionnaire, Laurence Skermer for help with coding and entering of data for the questionnaire, Dr Estelle Gilman, Regional Epidemiologist at West Midlands Regional Health Authority for demiologist at West for permission to use their mailing list and for encouraging a for permission to

A copy of the questionnaire can be provided on request.

1 Royal College of Physicians. Cvstic fibrosis in adults: recommendations for care of patients in the United Kingdom. mendations for care of patients in the United Kingdom.

2 British Paediatric Association Working Party on Cystic Fibrosis. Cystic fibrosis in the United Kingdom 1977-85: an improving picture. BMF 1988;297:1599-602.

3 Elborn JS, Shale DJ, Britton JR. Cystic fibrosis: current survival and population estimates to the year 2000 . Thorax 1991;46:881-5.
4 Phelan P, Hey E. Cystic fibrosis mortality in England and Wales and in Victoria, Australia. Arch Dis Child 1984;59:71-83.

5 Nielsen OH, Shiotz PO. Cystic fibrosis in Denmark in the period 1945-1981: evaluation of centralised treatment. Acta Paediatr Scand 1982:301(Suppl):107-19.

6 Corey $M$, McLaughlin FH, Williams $M$, Levison $\mathrm{H}$. A comparison of survival, growth and pulmonary function in patients with cystic fibrosis in Boston and Toronto. 7 Clin Epidemiol 1988;41:583-91.

7 Britton JR. Effects of social class, sex and region of residence on age at death from cystic fibrosis. $B M$ 1989;298:483-7

8 Simmonds EJ, Littlewood JM. Survival of patients with cystic fibrosis (correspondence), BM7 1989;298:828-9.

9 Robson M, Abbot J, Webb K, Dodd M, Walsworth-Bell J. A cost description of an adult cystic fibrosis unit and cost analyses of different categories of patient. Thorax 1992;47:684-9.

10 Secretaries of State for Health, Wales, Northern Ireland and Scotland. Working for patients. London: HMSO, 1989

11 National Health Service and Community Care Act 1990 London: HMSO, 1990

12 Walters S, Britton J, Hodson ME. Demographic and social characteristics of adults with cystic fibrosis in the United Kingdom. BMf 1993;306:549-52.

13 Littlewood JM, Kelleher J, Rawson I, Gilbert J, Firth J, Morton S, et al. Comprehensive assessment of patients at a cystic fibrosis centre identifies suboptimal treatment and improves management, symptoms and condition. 10th improves management, symptoms and condition. 10th International Cystic Fibrosis Congress, Sydney, 1988.
Exerpta Medical Asia Pacific Congress Series 1988;74:89. Exerpta Medical Asia Pacific Congress Series 1988;74:89.
Collins J. Care in the south west - a survey of cvstic fibrosi adults. Association of CF Adults LK, 1988

15 Walters S. Care for $C F$ adults - a surcey of patients. Association of CF Adults UK, 1989. 